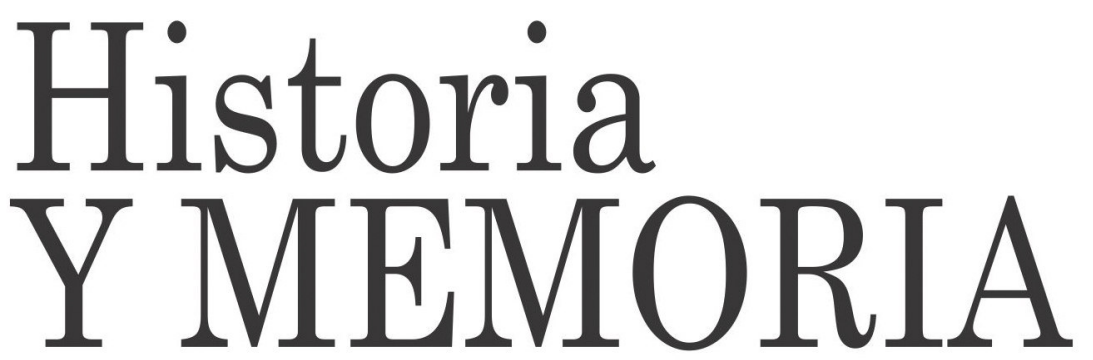

La antigua ciudad maya de Palenque en el debate ilustrado sobre la anticuaria indigena Americana

Antonio E. de Pedro Robles Páginas: 59 - 101 


\title{
La antigua ciudad maya de Palenque en el debate ilustrado sobre la anticuaria indigena americana*
}

\author{
Antonio E. de Pedro Robles ${ }^{1}$ \\ Universidad Pedagógica y Tecnológica de Colombia
}

Recepción: 05/12/2013

Evaluación: 15/01/2014

Aceptación: 05/04/2014

Artículo de Investigación e Innovación.

\section{Resumen}

El "descubrimiento" de la antigua ciudad maya de Palenque (Casas de Piedra) a mediados del siglo XVIII, en el interior de la selva chiapaneca, supuso un hecho significativo en el contexto del debate ilustrado que se va a dar, tanto en la España, como en los reinos y virreinatos americanos; en particular, en el caso de la Nueva España. Debate que tuvo como centro álgido de discusión dos aspectos que tratamos en este texto. El primero, hace relación al origen y autoría de estos restos arqueológicos, en base a dos supuestos: la participación de grupos humanos ultramarinos en su construcción o influencia; o la labor de unos determinados indígenas, distintos a los existentes en el siglo XVIII,

* Este texto forma parte de una investigación que se adelanta en relación con la anticuaria americana, particularmente que se refiere a México, siglos XVIII al XX.

${ }^{1}$ Doctor en Historia. Profesor de planta del Doctorado en Historia, Universidad Pedagógica y Tecnológica de Colombia. Integrante Grupo de investigación: Asociación Centro de Estudios Regionales REGION. Líneas de investigación: Historia cultural y visual latinoamericana. labra1957@gmail.com. 
capaces de hacer obras de una extraordinaria complejidad técnica y ornamental. El segundo aspecto que tratamos tiene que ver con el papel que va a jugar la creación de imágenes, por parte de los expedicionarios y dibujantes que los acompañan, y sus consecuencias, que llegan hasta nuestros días, en el proceso de conocimiento y divulgación del mundo prehispánico americano.

Palabras Clave: Anticuaria americana, imagen anticuaria, Palenque, arqueología americana, Antonio del Río, Juan Bautista Muñoz.

\section{The ancient Maya city of Palenque: Enlightened debate about this American indigenous antiquary}

\section{Abstract}

The discovery of the ancient Maya city of Palenque (stone houses) in mid-XVIII century within the Chiapaneca forest, stated a significant fact in the context of the enlightened debate which will be developed in Spain and the American kingdoms and viceroyships, especially New Spain. Two critical aspects of the debate will be considered in this paper. The first issue relates to the origin and authorship of these archaeological remains, based on two assumptions: the participation of overseas human groups in their building or influence; or the work of indigenous communities different to those existing in the XVIII century. These groups were able to create works of extraordinary technical and ornamental intricacy. The second issue deals with the role of the creation of images by the members of the expedition and the artists who accompanied them, as well as the consequences of the process of knowledge about the American pre-Hispanic world and its dissemination. 
Key words: American antiquary, antiquary image, Palenque, American archaeology, Antonio del Río, Juan Bautista Muñoz.

\section{L'ancienne cité maya de Palenque dans le débat éclairé sur les antiquités des indigènes américains}

\section{Résumé}

La «découverte» au milieu du XVIII siècle, à l'intérieur de la forêt du Chiapas, de l'ancienne cité maya de Palenque (des Maisons de Pierre), fût un évènement important dans le contexte du débat des Lumières tant en Espagne que dans les royaumes et vice-royautés d'Amérique, particulièrement en Nouvelle Espagne. Un débat focalisé sur deux aspects, dont nous nous occuperons dans ce texte. Le premier, l'origine et les auteurs de ces ruines archéologiques, où l'ont trouve deux hypothèses: que des groupes humains d'outre-mer auraient participé à sa construction ou qu'ils auraient eu une certaine influence; que dans ce travail seraient intervenus certains indigènes, distincts de ceux existants au XVIII ${ }^{\mathrm{e}}$ siècle, et capables de faire des œuvres d'une complexité technique et ornementale extraordinaire. Le deuxième aspect que nous traiterons renvoie au rôle joué par la création d'images de la part des expéditionnaires et des dessinateurs qui les accompagnaient; et leurs conséquences, jusqu'à nos jours, dans le processus de connaissance et divulgation du monde préhispanique américain.

Mots clés: Antiquités américaines, Image des antiquités, Palenque, Archéologie Américaine, Antonio del Río, Juan Bautista Muñoz. 
En 1745, Antonio Solís, cura de la localidad de Túmbala, comunicó a su familia haber descubierto, en un lugar conocido por los naturales como "Casas de Piedra", las ruinas de una "gran ciudad". El hallazgo, inicialmente no tuvo ninguna trascendencia más allá del ámbito familiar del cura. Hasta que, tiempo después, un sobrino de éste, todavía impresionado por el relato oído en su niñez de boca de su tío, se lo trasmitió a un compañero de estudios del Seminario de la Ciudad Real de Chiapas, llamado Ramón Ordóñez Aguiar. Ordoñez, convertido ya en presbítero, nunca olvidó el relato de su antiguo condiscípulo, y vivió desde entonces esperanzado con que le llegase la oportunidad de poder trasladarse personalmente al lugar para confirmar su hallazgo, oportunidad que nunca llegó.

Pero en el año de 1773 -ya habían pasado varias décadas desde el descubrimiento de Solís- el presbítero Ordoñez logró convencer a Esteban Gutiérrez de la Torre, teniente alcalde de Chiapas, para que, en su nombre, indagase sobre la existencia y estado de aquellas ruinas. Gutiérrez cumplió con el encargo y se trasladó al sitio en ese mismo año. Su visita fue registrada en una pequeña Memoria, en la que dio cuenta de lo que allí había visto y se atrevió a hacer especulaciones sobre el origen de la misteriosa ciudad. No obstante, y como ya había ocurrido en el caso del cura Antonio Solís, sus informaciones no lograron motivar a las autoridades de la Capitanía General de Guatemala.

Sobre la pequeña historia que hemos relatado, han surgido otras versiones, en las que cambian los protagonistas. Así, la investigadora española Paz Cabello, quien se ha ocupado en profundidad del asunto, ha señalado que hay una variante de la versión anterior en la que Ramón Ordóñez 
pierde protagonismo. ${ }^{2}$ La variante tiene su base en otras investigaciones previas presentadas por el historiador de la arqueología, el también español, Manuel Ballesteros Gaibrois, en el Congreso Internacional de Americanistas celebrado en Costa Rica en el año de 1959. Ballesteros armó, con base a cierta documentación epistolar (tres cartas: una del padre dominico Tomás Luís de Roca a don José Miguel de San Juan, fechada en noviembre 27 de 1792; y dos de este último al coronel Felipe de Sesma, escritas el 2 de diciembre de 1792 y el 2 de enero de 1793), ${ }^{3}$ una nueva teoría en la que un tal Fernando Gómez de Andrade, para entonces Alcalde Mayor de Chiapas e hijo de un antiguo miembro de la Audiencia de Quito, habría sido el primero en visitar "Casas de Piedra", después que lo hiciese el cura Antonio Solís. Ballesteros señala que fue Gómez de Andrade quien habría realizado la pequeña Memoria, y no Esteban Gutiérrez. ${ }^{4}$ Con más suerte que en la versión tradicional, Fernando Gómez de Andrade habría comunicado sus descubrimientos a los miembros de una tertulia literaria que se desarrollaba en la ciudad de Guatemala, y de la que él mismo era asistente, y a la que también pertenecían distinguidas personalidades como Fray Tomás Luis Roca. ${ }^{5}$ Esta tertulia, siempre según

${ }^{2}$ Paz Cabello, Politica investigadora de la época de Carlos III en el área maya. Descubrimiento de Palenque y Primeras excavaciones de Carácter Científico, (Madrid: Ediciones de la Torre, 1992).

${ }^{3}$ En relación con esta documentación presentada por Ballesteros al citado congreso, véase la publicación llevada a cabo por la Universidad Nacional Autónoma de México: Manuel Ballesteros, "Nuevas Noticias sobre Palenque en un manuscrito del siglo XVIII", Cuadernos del Instituto de Historia. Serie de Antropología, No. 11 (1960): 5-42. Contiene una "Introducción" de Alberto Ruz Lhuillier.

${ }^{4}$ Gómez de Andrade, según Ballesteros, era ya un aficionado a las antigüedades indias en su tierra natal de Quito. Hecho destacado por este investigador, como un "eslabón que une a la arqueología centroamericana con la de América del Sur del área andina”, Manuel Ballesteros, "Nuevas Noticias... 17.

${ }^{5}$ Fray Tomás Luís de Roca sería citado posteriormente por el presidente de la Real Audiencia de Guatemala José Estachería, como una de esas figuras a la que había pedido consejo sobre los descubrimientos de la ciudad, en la carta que éste le enviase a José de Gálvez el 13 de febrero de 1785. Manuel Ballesteros, "Nuevas Noticias... 8. 
Ballesteros, le hizo llegar a oídos del presidente de la Real Audiencia, José de Estachería, noticias sobre la antigua ciudad, incitándolo a iniciar investigaciones.

No obstante que Paz Cabello sigue la tesis de Ballesteros Gaibrois, ella no está del todo de acuerdo. Para esta investigadora, lo que realmente habría sucedido es que Ramón Ordóñez Aguiar debió dar parte de la existencia de las ruinas a Fernando Gómez de Andrade, y éste emprendió una primera visita al sitio, continuada de una segunda en la que realizó algunas excavaciones que le permitieron enviar un informe al teniente alcalde Esteban Gutiérrez. ${ }^{6} \mathrm{Y}$, siempre según Paz Cabello, Ramón Ordóñez debió confundir las visitas al no estar presente; o quizás terminó por sintetizarlas en una sola. Lo cierto, y sea como fuere, el presidente de la Real Audiencia de Guatemala, José de Estachería, se mostró muy receptivo a las noticias que le habían manifestado aquel grupo de tertulianos; ${ }^{7} \mathrm{y}$, en 1784, decidió - a un año escaso de su toma de posesión como presidente de la Audiencia- ${ }^{8}$ comisionar al alcalde del pueblo de Palenque, población cercana al lugar de las ruinas, José Antonio Calderón, ${ }^{9}$ para que emprendiese

\footnotetext{
${ }^{6}$ Según Ballesteros, Esteban Gutiérrez era joven, y su exploración del lugar estuvo vinculada a la de Gómez de Andrade. Manuel Ballesteros, "Nuevas Noticias... 19.

${ }^{7}$ En esto también Ballesteros propone otra variante según la documentación revisada, sería el maestro Roca y no Ordóñez quien le comunicase a Estachería lo hallado y le estimuló para que oficialmente se hiciese cargo del asunto.

${ }^{8}$ El Brigadier José de Estachería había accedido a la presidencia de la de la Real Audiencia de Guatemala en el año de 1783. Fue gobernado hasta diciembre de 1789, año en que regreso a España, obteniendo la gobernación de Pamplona y el grado de Mariscal de Campo.

9 Calderón había nacido en Santander, España. Hijo de Don Fernando Calderón Ladrón de Guevara, oriundo del valle de Cabezón de la Sal, en la misma región Cantábrica, y de doña Manuela Coz y Zevallos de la villa de Santillana. Entre los cargos públicos que desempeñó, destaca como Teniente de Alcalde Mayor del pueblo de Santo Domingo de Palenque y Subdelegado de la Intendencia y Administración de las Rentas Reales de Guatemala.
} 
una pequeña expedición y le informase detalladamente del asunto:

Haviendo llegado à mi noticia por conductos mui recomendables que à distancia de cosa de tres leguas de esa Población se descubrieron no ha muchos años los fragmentos menos equívocos de una mui populosa Ciudad, y cuyo examen puede producir luces para la mayor ilustración de los fastos de la Historia antigua, y moderna [...] y honor de la Nación, prevengo a Vuesa merced que sin pérdida de momento me informe de todas aquellas circunstancias que sirvan al previo conocimiento que necesito para formar idea del método, reglas, è instrucciones sobre que debo providenciar una exacta revisión de todo aquel lugar, para la colección de los monumentos, epígrafes, inscripciones, estatuas y demás piezas que indiquen más clara, y próximamente la antigüedad, particularidades, y fundación de aquella Ciudad. ${ }^{10}$

Como fue ordenado, Calderón se trasladó al sitio, y redactó un informe para el presidente, en el que detallaba las características de los edificios que él consideraba más importantes. Adjuntando los primeros cuatro dibujos que se realizarán sobre Palenque en el siglo XVIII, y que serán el inicio de toda una iconografía sobre las ruinas de enorme importancia para los estudiosos del tema. Asimismo, el santanderino Calderón fue el primero que desarrolló ciertas hipótesis sobre el origen y poblamiento de la ciudad. Según él, no había duda que lo que se encontraba oculto

10 José Estachería, "Oficio de José Estachería a José Antonio Calderón. Guatemala, 28 de noviembre de 1784 (en copia del 29 de enero de 1985)", en Paz Cabello. Política investigadora... 78-79. Las citas del informe de Estachería están tomadas del libro de Paz Cabello, donde el documento aparece como un anexo. Hemos eliminado las abreviaturas, que reproduce del original Paz Cabello, para así ofrecer una mejor compresión del texto. También se mantiene la ortografía original del documento. 
entre la frondosa selva chapaneca, había sido la corte de un rey que había dominado "todas estas tierras" como así lo demostraban sus ruinas de una relativa suntuosidad. ${ }^{11}$ Aunque, Calderón no dejó de destacar la tosquedad de sus formas: "la hobra es suntuosisima aunque si tosca en su fábrica, y por lo tanto de gran firmeza". ${ }^{12}$ Fue, a su vez, el impulsor de la teoría del origen fundador trasatlántico de la ciudad. Teoría que tuvo un largo impulso a lo largo del siglo XVIII entre los criollos ilustrados guatemaltecos y también en el Cosmógrafo de Indias de la Corte de Madrid, Juan Bautista Muñoz. Afirmaba Calderón en su informe a Estachería:

Señor no afirmo, ni asiento, que esta hobra fue de estos, sino que es un modo de pensar, ô dezir lo que otros dizen, ya que no puedo decir algo en aquel cónclave de Señores, que le hacen corte á Vuestra Señoria ô serían algunos nobles Señores de Nuestra España que por acá se entronisaron, cuando estubo ôprimida de la Morisma, viniendo por Agua hasta este Puerto, ô surgidero de Cathasajà: Tambien pareze que han dicho, que grandes familias de la Ciudad de Carthago vinieron a esta América, y no se supo el paradero. ${ }^{13}$

Pero Calderón no era un experto en estos temas de la anticuaria, y no debió sentirse con los conocimientos necesarios para poder estudiar en profundidad las ruinas. Por esa razón, recomendó la necesidad de mandar a alguien con mayores talentos, preferentemente para el dibujo y así conseguir que se "dé la perfección correspondiente a esas figuras":

${ }_{11}$ Paz Cabello, Política investigadora de la época de Carlos III en el área maya... 80.

12 Paz Cabello, Política investigadora de la época de Carlos III... 82.

${ }_{13}$ Paz Cabello, Política investigadora de la época... 83. 
[...] ademas de Ynteligente hombre de Polbo y Lodo, soldado de rasgo, que pueda caminar a pie y a la par conmigo: valiéndose muchas vezes de las manos para no dár en tierra, $[. .$.$] y entonces se conseguirà$ el que se dé la perfección correspondiente a esas figuras, que inserto hechas de pluma las mismas que están esculpidas, con mucho primor en las paredes de los Palacios de piedra, de cuia materia son todos; muchas ay de estraños vestidos, y plumages, mugeres con sus chiquelos a los brazos Agigantadas, muchos escudos, y ese género de Inscripción, ô Armas; que está dentro de un Palacio frente a la puerta y esa torre, que va hai media formada está en el Palacio grande, y desde ella se divisan los campos y Lagunas de todo este País. ${ }^{14}$

$\mathrm{Al}$ año siguiente, en enero 1785, tras haber recibido el informe de Calderón, y tal como lo había recomendado el santanderino, el presidente de la Real Audiencia preparó una nueva exploración que debía guiarse por un conjunto de instrucciones compuestas en 17 capítulos, redactadas por él mismo. ${ }^{15}$ En ellas, Estachería se preocupaba por atender los más diversos asuntos, particularmente la descripción de los edificios, estatuas, lápidas, escudos, jeroglíficos, divisas, etc. Es decir, todo el repertorio de temas propios de la metodología anticuaria ilustrada del momento. En este sentido, cabe señalar, que las instrucciones del presidente tienen antecedentes en el instructivo que el marino e ilustrado español Antonio de Ulloa había desarrollado en 1777, para el descubrimiento, acopio y catalogación de objetos anticuarios indigenas. ${ }^{16} \mathrm{El}$ documento estaba dividido en varias secciones: Geografía, Historia Natural,

${ }_{14}$ Paz Cabello, Política investigadora de la época... 82.

${ }_{15}$ Reproducidas en el libro de Paz Cabello, Política investigadora de la época... 83.

${ }^{16}$ Antonio de Ulloa. "Borrador de la instrucción sobre noticias de Geografía e Historia Natural del reino de Nueva España", en: Francisco de Solano. Antonio de Ulloa y la Nueva España. (México: UNAM, 1979), pp. CXLI-CXLII. 
Antigüedades y Botánica. En el apartado referente a las Antigüedades, Ulloa apuntaba que era necesario recopilar: "Los vestigios de antigüedades del tiempo del gentilío que subsisten en algún modo, en monumentos, vasijas herramientas, figuras y piezas de uso, etc."17

En otro documento posterior del mismo Ulloa, llamado Cuestionario, el marino era mucho más preciso en relación con los fines que animaban a la búsqueda y recolección de antigüedades indígenas:

Las Antigüedades dan luz de lo que fueron los Países en los tiempos más remotos, y por ellas se saca el conocimiento del aumento ó disminución que han tenido: con este motivo se procura investigar lo contundente á su averiguación, dando noticia de los vestigios que permanecen en algunos parages. ${ }^{18}$

Y, en un borrador anterior de este mismo Cuestionario, el ilustrado español ya insistía en la referencia a la categorización de documento de los restos anticuarios:

Las memorias de la antigüedad son las demostraciones verídicas de lo que fueron las gentes en los tiempos á que se refieren: por ellas viene á averiguarse lo que alcanzaron, el modo en que se manejaron, su gobierno y economía; y a este respecto lo que han adelantado ó perdido, lo numerosos de sus gentios, la industria, el valor, y las máximas de manejarse: sin los monumentos, que sin embargo de la ruina de los tiempos, se conservan en alguna parte, no habría documentos formales de donde inferirlos. ${ }^{19}$

${ }_{17}$ Antonio de Ulloa. "Borrador de la instrucción sobre noticias..., pp. CXLIXLII.

${ }^{18}$ Antonio de Ulloa. "Borrador de la instrucción sobre noticias..., pp. CXLICLII.

${ }^{19}$ Antonio de Ulloa. "Introducción Noticias Americanas", en Paz Cabello Paz Cabello, Política investigadora de la época... 33. 
De esta manera, los vestigios no sólo podían ofrecer noticias del pasado, sino que mostraban como había sido ese pasado e incluso el origen del mismo:

De ellos se comprende la semejanza que tuvieron unos pueblos con otros; y por este medio se llega, en aquella forma que es posible, á desentrañar su origen, que es una de las particularidades que más incitan el deseo. [...] Estos asuntos serían de la mayor confusión para el entendimiento, sino se les encontrase una solución regular en los vestigios de las cosas, en los usos, las costumbres, y las demás particularidades que descubre la investigación, ayudada de la inteligencia. ${ }^{20}$

En la España ilustrada del siglo XVIII, no había una clara definición de lo que era un "especialista anticuario", y era frecuente que los historiadores, así como otro tipo de eruditos, realizasen labores de su rastreo y estudio. En ese sentido, el mismo Ulloa deja patente esta consideración documental de las fuentes anticuarias:

Estas noticias serán de las ruinas de Edificios antiguos de la Gentilidad, de cualquiera materia que sean: de las paredes, cercas, muros, zanjas, ó fosos; de los entierros, ó sepulturas; de los Adoratorios, ó Templos; de las casas, ó chozas que habitaban, con expresión de sus figuras, capacidades, entradas y distribuciones internas. ${ }^{21}$

Por otra parte, los métodos y técnicas de esta anticuaria española se insertaban en una tradición desarrollada desde el siglo XVI. La epigrafía, la numismática y la toponimia, métodos tradicionales y usuales en la península, se seguían considerando en el siglo XVIII igualmente válidos en relación con el conocimiento del pasado; indígena americano.

${ }^{20}$ Antonio de Ulloa. "Introducción Noticias Americanas", ... 33

${ }^{21}$ Antonio de Ulloa. "Introducción Noticias Americanas",... 33. 
No obstante, pensemos por un momento cómo podría aplicarse un método como el numismático entre pueblos que no habían conocido la acuñación de monedas. Era obvio que ésta tenía poco que ofrecer en el conocimiento de las culturas de esos pueblos. Pero a pesar de ello, los españoles y europeos del XVIII no descartaban -incluso llegaron a obsesionarse- con la posibilidad de encontrar monedas entre los restos de los grandes imperios americanos, y al parecer el caso de "Casas de Piedra" no iba a ser la excepción. Es en este contexto donde se inscriben las instrucciones emitidas por Estachería para la segunda exploración de Palenque: su insistencia de informar detalladamente (incluyendo por supuesto nuevos dibujos) de las construcciones existentes dedicadas a la manufactura del beneficio de metales y la posible acuñación de monedas. Todo ello, con la finalidad de obtener pruebas fehacientes del origen ultramarino de su fundación.

De la misma manera, y siguiendo con los protocolos que la administración colonial española había incorporado tras las instrucciones redactadas por Antonio de Ulloa, Estachería redactó un oficio al entonces secretario de Estado de Indias, José de Gálvez, poniéndole en antecedentes sobre las gestiones realizadas hasta ese momento, y le adjuntó los originales del informe de Calderón, así como las nuevas instrucciones que había redactado para el nuevo viaje al frente del cual nombraría al arquitecto italiano Antonio de Bernasconi, quien por entonces trabajaba en la construcción de una nueva ciudad. ${ }^{22}$ Efectivamente, el 25 de febrero Bernasconi, acompañado por Calderón, inició su misión.

\footnotetext{
${ }^{22}$ Bernasconi y cuando fue nombrado por Estachería estaba encargado de la construcción de la nueva capital guatemalteca. Entre sus obras se encuentra el diseño del Arzobispado de la Nueva Guatemala de la Asunción, para el Arzobispo Cayetano Francos Monroy. Véase: José Estachería, "Oficio de José Estachería a José de Gálvez, Guatemala, 13 de febrero de 1785”, en Paz Cabello, Política investigadora... 112-115.
} 
Cuatro meses después, el 13 de junio, ya de regreso a Guatemala, el arquitecto italiano entregó su informe. Un informe bastante parco, aunque muy técnico en relación con la manera en que estaban hechas las construcciones principales que ya había descrito Calderón. ${ }^{23}$ Entre las cuestiones en las que el arquitecto hacía especial hincapié, era su reafirmación del término "Palacio" también empleado por Calderón, para identificar "la casa más principal", con lo cual daba a entender que la ciudad, si no había sido la sede de una corte, como afirmó Calderón, si había sido de una enorme importancia. ${ }^{24}$

No obstante, el ya anciano arquitecto no dejó de manifestar su ignorancia respecto al tipo de modelos arquitectónicos utilizados:

En su arquitectura no allo orden alguno de los que yo conozco, ni antiguo, ni moderno, y si solo que las Bovedas estan cerradas a lo Gotico. Las paredes tanto del Palacio, como de las demas casas, son de suma solidez, tanto que sobre las Bovedas se sostienen Arboles de una y media varas de diámetro. ${ }^{25}$

Y, al contrario que Calderón, Bernasconi no vio ni oratorios, ni baños, ni sepulcros, y sí algunas bóvedas que el italiano calificó de "calabozos". ${ }^{26}$ Tampoco descubrió fosos, ni murallas "o cosa alguna que denotase cautela contra enemigos"; aspectos, todos ellos, con los que Calderón había especulado para definirla como una "ciudad con fortificaciones". ${ }^{27}$

\footnotetext{
${ }^{23}$ Paz Cabello, Politica investigadora... 112-115.

${ }^{24}$ Paz Cabello, Política investigadora... 112.

${ }^{25}$ Paz Cabello, Política investigadora... 112.

${ }^{26}$ Paz Cabello, Política investigadora... 114.

${ }^{27}$ Paz Cabello, Política investigadora... 114.
} 
Respecto a las esculturas, el arquitecto señaló que no eran estatuas sino bajo relieves hechos de mezcla de estuco, y que no había señales de que una erupción volcánica, al estilo de lo ocurrido en Pompeya y Herculano, ${ }^{28}$ fuese la causante del abandono de la ciudad; más bien parecía "más verosímil, que allí la produjo el abandono de sus abitantes". ${ }^{29}$

Pero el aspecto más sobresaliente de sus conclusiones, estaba en relación con su afirmación de que dicha ciudad había sido habitada y construida por indios:

[...] es mui probable fuesen yndios según figura de las estatuas, modo de fabricar en las eminencias, $\mathrm{y}$ sin orden de calles, y cuadras; sin embargo de que la construcción de los edificios, no hace del todo incultos en el arte a los que lo fabricaron..$^{30}$

El arquitecto no había podido ser más claro: la teoría de los pobladores ultramarinos, fuesen estos cartagineses, romanos o antiguos cristianos huyendo de los moros, con lo que Calderón había especulado y que tanto interés había despertado en el presidente de la Audiencia y en la Corte de Madrid, no tenía cabida en el informe del italiano. Por el contrario, éste era más partidario de explorar otras vías interpretativas. En apoyo de su tesis, Bernasconi resaltaba el hecho de que los métodos y órdenes arquitectónicos allí empleados, no se parecían a ninguno que él hubiese

\footnotetext{
${ }^{28}$ Tras las excavaciones llevados a cabo en las antiguas ciudades romanas de Pompeya y Herculano, destruidas por la erupción del volcán Vesubio, por el rey de Nápoles Carlos VII, posteriormente coronado como rey del Imperio español, como Carlos III, las ruinas romanas se convirtieron en un referente de la arqueología imperial española; referente que inicialmente también paso a América, aunque pronto fue desechado. Véase: Félix Fernández Murga, Carlos III y los descubrimientos Herculano, Pompeya y Estabia. (Salamanca: Universidad de Salamanca, 1989).

${ }^{29}$ Paz Cabello, Política investigadora... 114.

${ }^{30}$ Paz Cabello, Política investigadora... 114.
} 
conocido en su ya larga trayectoria, a no ser porque ciertas bóvedas que le traían a la mente un recuerdo de ciertas formas góticas, lo que había allí visto no tenía referentes con la arquitectura, ni tampoco con la escultura europea.

Estachería envió el informe del arquitecto italiano a la Corte de Madrid, junto con los cuatro nuevos dibujos realizados por éste, en 1785. En Madrid, el informe fue recibido por el ministro Gálvez, quien, a su vez, lo remitió al cosmógrafo Juan Bautista Muñoz. Éste, una vez lo hubo leído, envió contestación al ministro de Indias, con fecha del 7 de marzo de 1786, en la que manifestaba la importancia de seguir profundizando en el estudio de Palenque. ${ }^{31}$ Además, le hacía saber al ministro Gálvez, que aplaudía el celo demostrado en este asunto por el presidente Estachería, y destacaba la importancia del lugar "por lo que pudiera ilustrar los origenes i la historia de los antiguos Americanos". ${ }^{32}$

Parecía entonces que Muñoz daba por bueno el carácter indígena de las ruinas; a unque, a decir verdad, no se daba por zanjado el asunto. En lo que el cosmógrafo estaba muy seguro era que las ruinas de Palenque suponían una demostración más de la "veracidad de nuestros Conquistadores e Historiadores primitivos en orden de los edificios hallados en la Nueva España i sus cercanias especialmente a la parte del mediodia". ${ }^{33}$ De este modo, Palenque se convirtió, particularmente para Muñoz quien por entonces había sido encargado por Carlos III de la redacción de una nueva y amplia historia de España y su imperio colonial con la cual responder a las acusaciones vertidas sobre su colonialismo

${ }_{31}$ Juan Bautista Muñoz, "Oficio de Juan Bautista Muñoz al Marqués de Sonora (Gálvez), dictaminando sobre las ruinas de Palenque. Madrid, 7 de marzo de 1786”, en Paz Cabello, Política investigadora... 118-121.

${ }^{32}$ Juan Bautista Muñoz, "Oficio de Juan Bautista Muñoz... 118.

${ }^{33}$ Juan Bautista Muñoz, "Oficio de Juan Bautista Muñoz... 118. 
por el historiador escoces William Robertson: The History of America, (Londres, 1777), ${ }^{34}$ en una "prueba documental" de enorme valor para demostrar las verdades de los Cronistas de Indias en relación con las grandezas descubiertas en el Nuevo Mundo.

Pero, lo que se sabía todavía sobre el asunto era insuficiente. Palenque debía ofrecer mayores pruebas de cómo ese mundo extraordinario había sucumbido antes de la llegada de los conquistadores, y ellos no podían seguir siendo acusados de su destrucción: "desconocido hasta ahora, i sin duda fue desamparada i arruinada siglos antes de la entrada de nuestros Españoles". ${ }^{35}$ Además, debía dejar en evidencia -pensaba Muñoz- cómo los llamados "indios nuevos" que habitaban la región, no eran los herederos de aquellos "indios constructores" tan extraordinarios. Estos, los "indios constructores", no tenían herencia en el presente chiapaneco del siglo XVIII.

En consonancia con lo anterior, Muñoz, en el mismo oficio enviado a Gálvez, aventura algunas hipótesis sobre su origen: "Prueva de haverlas dominado gentes poderosas, bien fuesen antiguos Tultecas [sin duda se refiere a los Toltecas], u otros de no inferior grandeza". ${ }^{36}$ Muñoz se apuntaba a la tesis de que la ciudad podría haber sido consecuencia del desplazamiento de estos grupos del altiplano mexicano:

Facil cosa seria dar especiosas conjeturas fundadas en las tradiciones Mexicanas acerca de los viajes i conquista de sus Mayores: tradiciones llenas de

\footnotetext{
${ }^{34}$ Véase al respecto de esta historia encomendada a Juan Bautista Muñoz. (1975). Historia del Nuevo Mundo. (México: Aguilar, 1975). La Obra viene precedida de un prólogo introductorio del historiador de la arqueología José Alcina Franch.

${ }_{35}^{35}$ Juan Bautista Muñoz, "Oficio de Juan Bautista Muñoz... 119.

${ }^{36}$ Juan Bautista Muñoz, "Oficio de Juan Bautista Muñoz... 119. (Entre corchetes nuestros).
} 
fabulas inverosímiles, pero que tiene un fondo de verdad; el qual procuro investigar con los hechos i documentos, huyendo el general vicio de formar sistemas. Para este fin conduce el presente descubrimiento, tanto mas apreciable, quanto menos frecuentes son hoi día los vestigios de semejantes antiguallas. ${ }^{37}$

Muñoz se negaba aceptar que dichas obras, por mucha importancia que tuviesen para el conocimiento del pasado indígena antes de la llegada de los españoles, fuesen obras equiparables a las que los anticuarios y arqueólogos europeos habían descubierto en la clásica Europa: "Estas aunque imperfectas i groseras, i en nada comparables a las obras de Europa, pruevan claramente que los pobladores antiguos de aquellos países eran superiores en saber i cultura a los del tiempo de la Conquista". ${ }^{38}$

No obstante, esas hipótesis tenían que comprobarse, así como desterrar del todo la idea de la emigración trasatlántica. Para ello, era imprescindible que Estachería mandase de nuevo a alguien a Palenque: a tomar nuevas muestras que ofreciesen "un nuevo reconocimiento a fin de aclarar ciertos puntos en que andan divididas las opiniones". ${ }^{39}$ Era necesario, volver a medir y describir, y, sobre todo, a hacer nuevos y mejores dibujos.

Entre las cosas que más impresionaban a Muñoz de la ciudad dos llamaban poderosamente la atención: el empleo de arcos que parecían de tradición gótica, mencionados por Bernasconi; y la construcción denominada "Torre", en cuyo interior aparecía un "caracol formando escalerilla, i contorno de ella muchas arquerias", porque Muñoz no

\footnotetext{
${ }_{37}$ Juan Bautista Muñoz, "Oficio de Juan Bautista Muñoz... 119.

${ }^{38}$ Juan Bautista Muñoz, "Oficio de Juan Bautista Muñoz... 119.

${ }^{39}$ Juan Bautista Muñoz, "Oficio de Juan Bautista Muñoz... 119.
} 
creía muy improbable que los arquitectos indios fuesen capaces de construir una escalera tan complicada:

Admirado quedé al leer tales expresiones, no haviendo creído jamas a los Arquitectos Yndios capaces de construir una escalera de caracol. Visto el absoluto silencio del perito en esta parte, quedan en pie mis dudas, i quisiera salir de ellas. Tambien dudo de los arcos i bovedas en que ambos convienen. Bernasconi, dice con palabras formales, que las bovedas estan cerradas a lo Gotico, i las figuras en techos de casas, en sotanos, i en alcantarillas o acueductos. Si tal huviese, serian estos edificios incomparablemente superiores en arte a los del Perú i de Mexico, en los quales nos e ha visto jamas cosa que se parezca a los arcos. Puertas formadas de tres piedras, esto es atravesaño i dos jambas, es quanto sabemos haver llegado la pericia Americana. ${ }^{40}$

\section{2}

El 15 de marzo de 1786, Muñoz dictó una Real Orden en la que se le solicitaba al presidente de la Audiencia de Guatemala "se continúe con su investigación". ${ }^{41}$ Estachería decidió seguir las instrucciones y recomendaciones de Muñoz. Para ello, pensó enviar nuevamente al arquitecto italiano, pero su muerte repentina le complicó las cosas. Obligado por las circunstancias, y al no tener a su disposición otros arquitectos, ni ingenieros militares que estaban ocupados en otras tareas, Estachería tuvo que echar mano del capitán de artillería Antonio del Río, un militar de oficio con una casi nula formación en este tipo de encargos. Antonio del Río se trasladó a Palenque

\footnotetext{
${ }^{40}$ Juan Bautista Muñoz, "Oficio de Juan Bautista Muñoz... 119, 120 y 121.

${ }^{41}$ José Estacheria. "Real orden al Presidente de Guatemala (Estachería). El Pardo, 15 de marzo de 1786”, en Paz Cabello, Politica investigadora... 126.
} 
acompañado del dibujante Ricardo Almendáriz, llegando al sitio el 3 de mayo de 1787 . El capitán conocía lo realizado por Calderón y Bernasconi, y "fue repitiendo exactamente los mismos pasos de sus predecesores, ampliándolos en los puntos y lugares que se le habían señalado". ${ }^{42}$ Midió los monumentos principales, describió su aspecto y tomó "muestras" de los mismos, para ello realizó excavaciones en más de un lugar; y, finalmente, redactó una memoria, acompañada por los 25 dibujos que realizó Almendáriz. ${ }^{43}$

Las labores en Palenque terminaron en junio de 1787, fecha en que aparece firmado el nuevo informe de Antonio del Río. A su vuelta a Guatemala, Estachería puso al ingeniero militar José de Sierra a preparar copias del mismo, dejando una copia para sus archivos. Un año después, todos estos materiales fueron enviados a España, al sucesor de José de Gálvez, Antonio Valdés, marqués de Sonora, junto con una nota en la que se le notificaba de los resultados obtenidos; más un arco con siete flechas de los indios lacandones, actuales habitantes de la región. Todo ello fue remitido por Valdés al Real Gabinete de Historia Natural que había fundado en Madrid el rey Carlos III en el año de 1771, aunque no abrió sus puertas hasta el 4 de noviembre de 1776 . Pero, al parecer, solo una copia

\footnotetext{
${ }^{42}$ Paz Cabello, Política investigadora... 126.

43 De esta Memoria, se hizo posteriormente una primera edición en Londres en 1822, con el título: Description of the Ruins of an Ancient City. Discovered near Palenque...from de Original Manuscript Report of Captain Don Antonio del Rí: Followed by Teatro Crítico Americano...by Doctor Paul Felix Cabrera... Esta obra fue ilustrada con 15 grabados realizados por Jean F. Waldeck, basándose en los dibujos de Armendáriz. La primera edición española no aparece hasta 1939, realizada por Manuel Ballesteros. Posteriormente, en 1946, Castañeda Paganini realizó otra edición en México. La Biblioteca Nacional de Madrid en su sección de Incunables y libros raros, guarda un ejemplar de la obra original de Antonio del Río, con 15 de los 26 dibujos. Hay también una copia completa en la Biblioteca del Palacio Real de Madrid. El informe original se encuentra en el Archivo del Museo de Ciencias Naturales; aunque hay otro manuscrito en la Academia de la Historia, también de Madrid.
} 
del informe y los objetos de las excavaciones llegaron a dicho gabinete: los dibujos originales de Almendáriz desaparecieron. Hoy se sabe que éstos quedaron en las oficinas de la Junta de Estado junto con el informe original a cargo del I conde de Floridablanca. Éste mandaría hacer la copia que se conserva actualmente en la biblioteca del Palacio Real; aunque los dibujos originales jamás han aparecido.

El Informe de Antonio del Río en relación con el informe de su antecesor, el arquitecto italiano Bernasconi, constituyó un cambió de rumbo en el proceso de interpretación y adjudicación de la construcción de las obras de la ciudad. En defensa de esta tesis, quisiera señalar lo siguiente. En primer lugar, el capitán utilizó nuevos términos para referirse a las construcciones de Palenque; así, pasó de calificar las edificaciones de "palacios" a "casas". Cambio de terminología que no se me antoja una cuestión menor, y sí, por el contrario, responde a una nueva orientación en la interpretación del conjunto urbanístico. En este sentido, ya no estaríamos ante un conjunto calificado de "ciudad-corte", tal como Calderón definió y Bernasconi reafirmó, sino que estaríamos tan sólo ante los restos de una "ciudad". El término "casa", fue empleado por Antonio del Río de manera frecuente, incluso para aquellos edificios que con anterioridad habían llamado poderosamente la atención de Estachería y de Muñoz, caso de la casa en la que se encontraba el famoso "arco gótico" apreciado por el arquitecto italiano. Incluso al considerado hasta entonces "Palacio", Antonio del Río tiene mucho cuidado en definirlo tan sólo como "Casa más grande". En definitiva, está claro que el Capitán utilizó intencionadamente el cambio de términos para tratar de superar las confusiones a las que había dado lugar la utilización del término "palacio". 
En segundo lugar, quiero detenerme en cómo Antonio del Río se ocupó de uno de los elementos arquitectónicos que despertaron más interés para Muñoz, me refiero a la famosa "Torre" con su escalera en caracol. Al respecto, la describe de la siguiente manera:

[...] se presenta la Torre [...] de diez varas de elevación y quatro Cuerpos, à que se añadiria el quinto con la Cupula que es regular tubiese, y aunque estos ban en disminución sin adornos, como manifiesta su dibujo, no deja de ser su idea, bastante particular e ingeniosa. ${ }^{44}$

Como se puede comprobar, el capitán no logró disipar las dudas sobre la estructura de la escalera, ni tampoco en relación con los arcos y sus supuesta "forma gótica". Tampoco aclaró mucho las preocupaciones de Muñoz sobre las migraciones toltecas y su influencia sobre el origen de Palenque. Pero, lo que si resulta más llamativo de sus observaciones, es que apunta a una "versión mejorada" de la tesis trasatlántica de Calderón:

Por la elección de establecerse en iguales sitios, y por el aqueducto de piedra subterraneo, de mucha solidez y permanencia, que atraviesa por debajo de la casa grande, se pudiera inferir que estas gentes tubieron alguna analogía y trato con los Romanos: no por que yo me persuada, hayan llegado à este Terreno aquellos conquistadores, sino por que se deja congeturar con fundamento, que algunos de otra Nación culta se asomaron por estos Payses, de quienes, durante el espacio de su detención, habrían recivido estos naturales alguna idea de las Artes, como Recompensa de su hospitalidad. [...] que en sus fabulosas supersticiones parece

${ }_{44}$ Antonio del Río. "Informe de Antonio del Río. Palenque, 24 de junio de 1787”, en Paz Cabello, Política investigadora... 138. 
bemos retratada la idolatria de los Phenicios, Griegos, Romanos y oltros; Y por tanto es de recelar que algunas de estas Naciones adelantaron sus conquistas hasta este Pais, en el qual se conoce no permanecerían mas tiempo que el que bastò à estas gentes Yndias para retratar sus ideas, y tomar un rudo y tosco estilo de las artes, que les querrian enseñar. ${ }^{45}$

La novedosa conjetura a la que llegó Antonio del Río, no sólo consistió en admitir que los indios habían sido incapaces de realizar, en base a sus propios conocimientos, obras de tal complejidad arquitectónica y decorativa, sino, además, que las supuestas "enseñanzas ultramarinas" recibidas, no habían sido "reproducidas" con la necesaria elegancia y majestuosidad que se esperaría teniendo tan "excelsos maestros". En pocas palabras, los indios constructores de Palenque habían sido sólo unos "rudos" y "toscos" imitadores de un modelo artístico superior que no supieron captar a plenitud.

Es interesante comprobar cómo las conclusiones a las que llega Antonio del Río concuerdan con los comentarios que circulaban entre la tertulia de notables establecida en Guatemala. Según nos ha indicado Manuel Ballesteros:

[...] aquellas ruinas no eran "cosas de indios", y uno y otros, de un modo o de otro, explicaban la construcción de la ciudad (asi como del Río la atribuiría a algún viajero romano) por medio de emigraciones de cartagineses, colonizaciones de fenicios y -sobre todo- al comercio que para ellos indudablemente existió entre el Viejo Mundo preclásico y el Nuevo Mundo. San Juan (aduciendo tan pronto a los egipcios como a Ceres y Proserpina, en una verdadera indigestión de

$\overline{45}$ Antonio del Río. "Informe de Antonio del Río... 133 y 145. 
erudición humanística) piensa incluso en el aprovisionamiento áureo de Salomón. ${ }^{46}$

Teniendo presente la información de Ballesteros, cabe suponer que la tesis del capitán Antonio del Río se presentó a modo de un "sincretismo" entre la interpretación de Bernasconi y las ideas desarrolladas por Calderón; es decir, un "sincretismo" que no aportó gran cosa en el avance de la investigación, y sí, por el contrario, siguió manteniendo vivas las dudas sobre la autoría y el origen de la ciudad: si el informe de Bernasconi fue demasiado sucinto, y sus opiniones estaban fundadas en base a un conocimiento "desapasionado" de la arquitectura que no fue recibido con mucho entusiasmo por Guatemala y Madrid, los argumentos de Antonio del Río tampoco fueron capaces de rechazarlo, ni de contradecirlo. En cuestión de descripción y de análisis arquitectónico, Antonio del Río no aportó más de lo que ya el arquitecto italiano había ofrecido.

No obstante, la gran riqueza del Informe de Antonio del Río se puede concretar en dos aspectos: el primero, propició una excelente colección de dibujos realizados por Ricardo Almendáriz; y, en segundo lugar, el tipo de relación que quedó establecido entre estos dibujos y las descripciones de los mismos realizadas por Antonio del Río, se convirtieron en un modo novedoso para caracterizar la anticuaria indígena americana bajo las perspectivas del modelo ilustrado. En las próximas páginas nos vamos a detener en el análisis del modo de visualidad empleado por Almendáriz y la manera en cómo las imágenes, junto con las descripciones de Antonio del Río, conforman una unidad discursiva en relación con la antigua ciudad indígena de Palenque.

${ }_{46}$ Manuel Ballesteros, "Nuevas Noticias sobre Palenque en un manuscrito del siglo XVIII", Cuadernos del Instituto de Historia. Serie de Antropología, No. 11 (1960): 17. 
Si Juan Bautista Muñoz fue insistente en la necesidad de realizar nuevos dibujos sobre los edificios y restos anticuarios de Palenque, prestando particular atención a las descripciones de Calderón y Bernasconi, es porque Muñoz, como la ilustración anticuaria europea del momento, estaban consciente de que la incorporación de un dibujante capaz de realizar excelentes dibujos, "bien figurados" y "viendole copiado con exactitud hallarémos una conformidad de donde pueden sacarse utiles conjeturas", ${ }^{47}$ era fundamental en una empresa de estas características. Ya se había comprobado en el caso de Pompeya y Herculano el gran valor que tenías los dibujantes y grabadores no sólo para crear una galería de imágenes acorde con la grandeza de los descubrimientos, sino también, como referente fundamental para la divulgación y publicitación del sitio, que pasó a ser un lugar de peregrinación para los anticuarios de la antigüedad clásica europea.

El colofón del gran proyecto anticuario sobre Pompeya y Herculano del rey Carlos de Nápoles, lo constituyó la fundación de la Accademia Ercolanese instaurada el 13 de diciembre de 1755, a escasos cuatro años de ser nombrado este rey sucesor de la Corona española bajo el título de Carlos III. Unos año antes de fundada formalmente esta academia, en 1752, Ottavio Antonio Bayardi, había sido comisionado por el rey para ofrecer la publicación del Prodromo delle antichitá d' Ercolano. Obra, que tras ocho años de intenso trabajo, vio la luz en cinco volúmenes, en el año de 1752. El primer tomo dedicado a la pintura, se editó en 1755. En los años sucesivos (1760, 1762 y 1765) se publicaron tres tomos más de pinturas antiguas de la ciudad de Herculano; y, en el año de 1767, el tomo I dedicado a los Bronzi de Ercolano. En el año de 1754 se había publicado otra obra importante: el Catalogo degli

$\overline{47}$ Juan Bautista Muñoz, "Oficio de Juan Bautista Muñoz... 121. 
antichi monumenti di Ercolano, editada, por primera vez, en Nápoles. Esta obra, de patrocinio real, encumbraba la labor anticuaria del rey Carlos III con el título del "Rey arqueólogo". ${ }^{48}$

Pero, sin duda, la labor del dibujante como fundamental en los descubrimientos y excavaciones arqueológicas emprendidas por la Corona española, vino de la mano del viaje emprendido por Luis José Velázquez (1722-1772) marqués de Valdeflores, entre los años de 1752 y 1754 y antes de la llegada de Carlos III al trono de España. El marqués incorporó, por primera vez en la historia de la anticuaria española, la labor de un dibujante profesional que garantizaba "imágenes fidedignas" de los objetos y monumentos realizados "in situ", evitando así la falsificación de los descubrimientos. ${ }^{49}$

Volviendo a nuestro caso de Palenque. Según la historiadora española Concha García Sáiz, fue el investigador Castañeda Paganini quien le atribuyó inicialmente la elaboración de los dibujos del viaje de Antonio del Río a Ricardo Almendáriz. Años después, H. Berlin confirmó la atribución apoyándose en unos datos ofrecidos por el padre Ramón Ordóñez y Aguiar (en este caso Ricardo aparece como Ignacio) quien hacía referencia a unas informaciones que este artista le habría facilitado en 1790. Además, Berlín había localizado en el Archivo General del Gobierno de Guatemala, los "Comprobantes a los gastos ocasionados por el pintor Ignacio Armendáriz, por copias de las figuras de las ruinas de Palenque. Año de 1787”. ${ }^{50}$ Asimismo, confirmó cómo en Guatemala quedó una

${ }^{48}$ Gloria Mora. Historias de mármol. La Arqueología clásica española en el siglo XVIII. (Madrid: CSIC, 1998).

${ }^{49}$ Gloria Mora. Historias de mármol...

50 Concepción García Saíz, "Antonio del Río y Guillermo Dupaix. El reconocimiento de una deuda histórica", Anales del Museo de América, No. 2 (1994): 100. 
copia de la versión original de los dibujos realizados según ya lo estableció Castañeda Paganini en 1946. De esa copia se sacaría otra que sería la que habría puesto "en limpio" el ingeniero José de Sierra por orden de Estachería, como ya hemos visto más arriba. Esta “copia”, el presidente de la Audiencia la habría mandado a Madrid junto con el informe de Antonio del Río, y sería la que perdería en manos del conde de Floridablanca. En Madrid, otro artista, que García Sáiz identifica con el nombre del "copista de Madrid", realizaría una nueva copia que ha sido la que hemos manejado la mayoría de los que nos hemos ocupado de este asunto, y que se ha considerado como "propia" de Almendáriz. ${ }^{51}$ En definitiva, estaríamos frente a un largo proceso de originales y copias que fueron realizadas tanto en Guatemala como posteriormente en España.

¿Pero qué sabemos del método de trabajo emprendido por Antonio del Río y Ricardo Almendáriz? Actualmente no podemos definir si la labor del dibujante Almendáriz se realizó toda en Palenque o la terminó a su regreso a la capital de Guatemala. Mi opinión es que habría realizado "in situ", siguiendo la tradición impuesta por el artista del marqués de Valdeflores, unos dibujos a modo de bocetos, y que el trabajo se concluiría a su regreso a la capital; ello, independientemente del trabajo que debió realizar el ingeniero José de Sierra al ponerlo "en limpio". Me apoyo en esta afirmación en dos aspectos. El primero, es el que resulta de examinar las características técnicas del trabajo desarrollado por Almendáriz. Es difícil considerar que unas láminas en las que aparecen numerosas figuras (algunas de ellas de difícil ejecución por lo abigarrada de la composición) hayan sido realizadas en un ambiente climático particularmente "hostil" para el trabajo en papel, y dadas las excesivas condiciones de humedad. Además, y en apoyo a lo anterior, hay que tener presente que el

${ }^{51}$ Paz Cabello y García Saiz utilizan esta "copia” para su estudio. 
trabajo de Almendáriz se caracteriza por su limpieza, su gusto por el detalle y un delicado juego de volúmenes, que obliga a un dibujante, según modelos académicos plenamente instaurados en la época, a seguir distintas fases en la elaboración de una lámina. ${ }^{52}$

El segundo aspecto, tiene que ver con la existencia de precedentes previos. María de la Cruz Paillés y Rosalía Nieto Calleja señalan que el trabajo del arquitecto italiano Bernasconi, en relación con ciertos mapas del lugar como el identificado por ellas como "Mapa 2", les llevó a pensar en la posibilidad de que:

[...] durante el tiempo en que permaneció en el sitio, solamente hubiere realizado bosquejos y tomado medidas de los edificios, registrando los elementos decorativos que a su juicio eran los más importantes [...]. Al observar los planos originales en Sevilla, nos pudimos percatar de la nitidez y limpieza con lo que fueron realizados, lo que nos permite inferir que fueron dibujados y acuareleados en gabinete, puesto que las condiciones ambientales imperantes en Palenque no se lo hubieran permitido. ${ }^{53}$

Estas conclusiones, a las que ambas investigadoras han llegado después de una interesante e imprescindible investigación, bien pueden aplicarse al caso de Almendáriz. Éste, como artista preocupado por su trabajo, estaría interesado en que sus dibujos fuesen de la misma calidad que los de su antecesor.

${ }_{52}$ Antonio E. de Pedro Robles. El diseño científico: ss. XVI al XIX, (Madrid: Akal, 1999).

${ }_{53}$ María de la Cruz Paillés y Rosario Nieto, "Palenque en el siglo XVIII, primeras expediciones de la Corona Española: Joseph Antonio Calderón y Antonio Bernasconi”, en Laporte, J. P; Escobedo, H; Villagran, S (edts). Memorias. VI Simposio de Investigaciones Arqueológicas en Guatemala, (Guatemala: Museo Nacional de Arqueología y Etnología, 1992): 483. 
Ahora bien. Una duda fundamental no deja de asaltarnos en relación con el trabajo de Almendáriz: ¿Cuánto de su trabajo quedó después de que el arquitecto Sierra hiciese las "correcciones" encomendadas por Estachería? Recuérdese, que hay constancia de que el texto de Antonio del Río fue pasado "a limpio" también por este ingeniero, tal y como lo menciona Paz Cabello, y que aparentemente por esa razón, Estachería tardó un año en enviar a Madrid los resultados del viaje. Lo que tampoco sabemos, y esta es otra cuestión en la que no han entrado los investigadores, es por qué el texto y los dibujos de Del Río y Almendáriz tuvieron que ser puesto en limpio: ¿Qué no le gustó al presidente de la Audiencia? ¿Acaso Sierra, por consejo de Estachería, reformuló las impresiones y conclusiones de Antonio del Río?

Todos estos interrogantes son muy difíciles de contestar. Paz Cabello considera "naturales" las explicaciones dadas por Estachería:

Sierra lo revisó introduciendo las correcciones que consideró oportunas, ya que Estachería pensaba que un arquitecto o un ingeniero tenían una formación más apropiada que un oficial de artillería para acometer esta misión. ${ }^{54}$

Pero, esta respuesta no nos aclara mucho sobre el asunto que estamos planteando: ¿Fueron las correcciones sólo de estilo o también interpretativas? ¿Cuánto del que llamamos texto de Antonio del Río es obra del ingeniero Sierra? ¿Por qué alguien que no había estado en Palenque fue comisionado para hacer correcciones?

Las dudas son muchas y las respuestas, vuelvo a recalcar, hasta ahora muy pocas, ya que no ha aparecido o no existe la documentación que nos permita ofrecer pruebas

${ }^{54}$ Paz Cabello, Política investigadora... 41. 
inequívocas. Pero si creo, que es bueno tener presentes estos interrogantes a la hora de emprender cualquier estudio del texto y los dibujos de la expedición del capitán Antonio del Río. Sobre todo porque el trabajo de Sierra no parece haber constituido, dada la demora de un año, un mero proceso de "trasferir información"; más bien una "puesta al día" del trabajo del dibujante y del Capitán.

Pero hay otro aspecto que enreda aún más lo que venimos planteando. Porque si damos por buenas las afirmaciones de Concha García Saiz, quedaría por saber qué quedó del trabajo realizado por Almendáriz/Sierra en la copia de los dibujos realizada por el "copista de Madrid". Un aspecto éste no menos menor que los anteriores.

Pero avancemos y detengámonos ahora en el análisis de algunas imágenes en relación con su texto descriptivo. Análisis que nos permitirá ir comprendiendo el procedimiento empleado por el Capitán Antonio del Rió y el dibujante Ricardo Almendáriz. Por ejemplo, en el caso de la descripción de la decoración que aparece a los pies de las ventanas de la denominada "gran Casa", el informe de Antonio del Río señala:

[...] se ben por decoración de la Sala, unos Medallones, ò cartones de estuco con diferentes adornos de lo mismo de la manera que se halla Copiado y lo demuestra la figura $3^{\text {a }}$ : Es de Creer que las Cavezas, cuyos Vestigios se perciben denotarian los Vustos, con la serie de los Reyes, o señores a quienes obedecían estas gentes. ${ }^{55}$

Del Río nada nos dice sobre la forma de las cabezas, al parecer todo lo remite a la contemplación de "la figura 3” (Imagen 1). Veamos otro caso similar:

${ }_{55}$ Antonio del Río. "Informe de Antonio del Río... 137. 
La figura 15 representa al parecer alguno de sus Dioses, sentado mujerilmente sobre un animal en los terminos que manifiesta ella misma: se puede creer signifique al Dios de las aguas, al modo que los antiguos solían figurar el Pegaso en los propios términos. ${ }^{56}$

En éste nuevo ejemplo, encontramos otro factor añadido con respecto a la imagen que acompaña a la descripción. Antonio del Río relaciona la figura representada de Pegaso, poniendo sobre aviso al lector para que tenga presente esta condición a la hora de proceder a su contemplación e interpretación. Ello, obliga al lector, a un ejercicio comparativo entre una imagen que se muestra (el dibujo de Almendáriz) (Imagen 2), y una imagen ausente e indefinida, pero que puede ser "elegida" de un repertorio visual histórico sobre la imagen de Pegaso, como nosotros mismos hemos hecho (Imagen 3).

La forma Pegaso a la que se refiere Antonio del Río es una forma legitimada histórica y cultural por la tradición visual de occidental que identifica como Pegaso una determinada imagen, independientemente de cuestionarse su existencia real. Como tal, sus características formales deben responder a una especie de "caballo con alas". Así, cuando Antonio del Río solicita al lector que ante la imagen descrita de Palenque tenga presente a la forma de un Pegaso, lo que está solicitando no es que lo compare formalmente, sino que tenga presente su carácter simbólico: el Pegaso para los griegos y romanos; el dios representado para los habitantes de Palenque. En este sentido, la imagen ausente de Palenque queda definida no como imagen a modo de "reflejo" de una "cosa real", en el sentido que el realismo ingenuo entiende, sino como símbolo cuyo referente visual e histórico le es desconocido para Del Río. Es decir, para Antonio del Río el objeto de

$\overline{{ }^{6}}$ Antonio del Río. "Informe de Antonio del Río... 139. 
Palenque que aparece en el dibujo de Almendáriz es un enigma sin resolución, que él extiende al propio lector en

relación con el origen imaginario mítico-religioso que dio origen a la imagen palencana de la "Figura 15".

Ahora bien. Lo único que ha quedado claro del proceso comparativo llevado a cabo, es que ambas imágenes parecen "tener un origen" no en la representación de "objetos reales", a modo de imágenes reflejo, sino en constructos visuales destinados a una misma categorización míticoreligiosa del mundo. Esta consideración que se desprende de la descripción de Antonio del Río es de gran importancia para definir el modelo de anticuaria que se está manejando. Antonio del Río es consciente que los objetos no son objetos artísticos como tales, sino que son objetos relacionados con el ámbito mítico-religioso, independientemente de que se tenga o no información previa sobre ese mundo. Para la anticuaria ilustrada española de la que forma parte Antonio del Río, los grupos humanos, por muy distintos que estos sean, son grupos que pasan por fases de relación con su entorno, con sus creencias y valores, de manera semejante. Así, como ocurría en la antigüedad clásica greco-latina, en el mundo de la ciudad de Palenque las formas arquitectónicas y las esculturas también están relacionadas con lo mítico y lo religioso.

La segunda observación que queremos destacar en relación con el papel de la imagen en el proceso descriptivo de la ciudad de Palenque, tiene que ver con el hecho mismo de su conformación formal. Sí, como hemos visto, Calderón realizó dibujos muy esquemáticos, a modo de emblemas (Torre, Palacio, etc.) (Imagen 4), y, más tarde, Bernasconi fijó su interés en describir aspectos estructurales de las construcciones más relevantes (Imagen 5); con Ricardo Almendáriz la visión se amplió a múltiples objetos. No obstante, el dibujante se detuvo en algunos objetos que ya habían sido tratados por sus predecesores, por ejemplo, 
el caso de la famosa "Torre", que Del Río describió de la siguiente manera:

Dando la vuelta por la vanda del S. se presenta la Torre que señala la figura de diez y seis varas de elevación y quatro Cuerpos, à que se añadiria el quinto con la Cupula que es regular tubiese, y aunque estos ban en disminucion y sin adornos, como manifiesta su dibujo, no deja de ser su idea, bastante particular e ingeniosa. ${ }^{57}$

La descripción del capitán se detiene en las medidas de elevación de la torre, el número de cuerpos que la componen y la supuesta cúpula (Imagen 6). Pero no entra en detalles sobre su forma, a no ser que es "particular e ingeniosa". Ahora, si comparamos esta descripción con el dibujo realizado por Almendáriz, éste es menos relevante e incluso algo incoherente. Antonio del Rio habla de cúpula, elemento que está también en las descripciones de sus predecesores, pero dicha cúpula falta en el dibujo de Armendáriz. La pregunta es: ¿El ingeniero Sierra habría modificado el dibujo inicial de dibujante eliminando la cúpula? Pregunta sin resolver. Pero, mientras en el dibujo de Calderón la torre es sólo un emblema torre, y Bernasconi la incluye en una representación de conjunto, apoyándose en un texto descriptivo en que se resaltan cuestiones relativas a la manera en que funciona la supuesta escalera de caracol; la "Torre" de Almendáriz ni ofrece información sobre el interior, ni de la estructura de la supuesta escalera. El haber aislado Almendáriz la "Torre" del conjunto al que pertenece -hecho que resulta chocante para muchos investigadores- ${ }^{58}$ fue una manera, en mi opinión, de centrar la atención sobre su aspecto exterior, y no complicarse con aspectos para los que ni él, ni Del Río tenían respuesta; y es

\footnotetext{
57 Antonio del Río. "Informe de Antonio del Río... 138.

58 Pascal Mongne afirma que el dibujo de Almendáriz está muy alejado "de la verdad arqueológica", y que este alejamiento se debe a una "visión europeizante, hasta simplista, que revela una interpretación neo-clásica" (Mongne, 2009: 194).
} 
más: a los que querían quitarle importancia. Pensemos que Muñoz vería sólo aquello que los dibujantes le mostrasen.

Pero vayamos al encuentro de algunos otros dibujos de Almendáriz y comparémoslo con otras dos imágenes. En este caso, una fotografía del Museo de América de Madrid, y un calco realizado por la arqueóloga norteamericana Merle Green. Para ello, tomemos como referencia el dibujo "Fig. 16" que aparece en Paz Cabello como lám. 32, en el que aparece representado el "pie derecho" del llamado "Trono del Palacio de Palenque" y que actualmente se exhibe en la colección permanente del ya mencionado Museo de América (Imagen 7). ${ }^{59}$ Almendáriz, y como en los otros ya casos mencionados tenemos que tener presente la intervención en el dibujo del ingeniero Sierra aunque no sepamos en qué consistió exactamente esta intervención, recoge tanto la escena frontal del "pie", como su lateral derecho en el que aparecen representados unos glifos. La perspectiva elegida por Almendáriz resulta algo artificiosa, intencionadamente oblicua, con el fin de poder mostrar ambos elementos en un mismo plano visual. Otro dibujo complementario a éste, identificado como "el número 17" en la obra de Paz Cabello, ofrece mejores detalles de los glifos que adornaban el grueso del tablero del asiento del trono (Imagen 8). Ahora bien. Comparemos el dibujo identificado como "Fig. 16", con la fotografía del objeto (Imagen 9), y centremos nuestra atención en la mano izquierda que aparece tanto en el dibujo como en la fotografía. En el dibujo se ha omitido información en relación con lo que muestra la fotografía: varias marcas a modo de puntos horadados en la piedra.

En el modelo de representación visual y artístico manejado por Almendáriz -y esta es una característica extensible a el dibujo anticuario del siglo XVIII- no existe una

59 Paz Cabello, 1992: láminas 32 y 33. El relieve, de piedra originalmente policromada, estaba situado en una sala del lado este del patio Central del Palacio, y Antonio del Río ordenó cortarlo en la mitad de su grueso para así facilitar su trasporte primero a Guatemala y luego a España. (Cabello, 1992: lámina 33). 
intención de utilizar la imagen como un registro pormenorizado del objeto al modo de lo que se pretende con la fotografía de inventario del museo. La intención de Almendáriz es crear una imagen fruto de una experiencia visual frente al objeto "in situ". Una experiencia desarrollada a raíz de una relación estética y artística con el objeto. En algunos casos, como en los calcos (sistema de reproducción utilizado por muchos arqueólogos modernos) este tipo de imágenes tienen una intención muy distinta a las intenciones de la imagen realizada por Almendáriz. Si tomamos el calco realizado por la arqueóloga Merle Green del bajorrelieve central del Templo del Sol, también en Palenque (Imagen 10) y lo comparamos con el dibujo realizado por Almendáriz de ese mismo bajorrelieve (Imagen 11), también reproducido por Paz Cabello ${ }^{60}$, el calco de Green funciona como una imago en el sentido que estableció el teórico griego, Plinio el viejo: concepto de semejanza e imagen matriz. ${ }^{61}$ Es decir, la imago de la que nos habla Plinio, no es una imitación en el sentido artístico y estético del término: "no es fáctica, y no requiere ninguna idea". ${ }^{62}$ Por el contrario, la imagen de Almendáriz si es una imitación, en tanto que hay una búsqueda estética y artística, situación que no ocurre con el calco, entendido como una "imagen matriz producida por adherencia, por contacto directo de la materia". ${ }^{63}$

Almendáriz se sitúa en la otra orilla de la propuesta de Plinio. Su imagen es el resultado de una experiencia estética y artística en la observación y representación de un objeto desconocido, extraño a la cultura occidental en la que él y Del Río están inmersos; es decir, hay una intencionalidad de realizar una representación del objeto en base a una idea. Idea resultado de la puesta en práctica de una visualidad

${ }^{60}$ Imagen 13, "Calco del bajorrelieve central del Templo del Sol, tomado de Green, 1985" Paz Cabello, 1992: lámina 47.

${ }_{61}$ Didi-Huberman, G. Atlas ¿Cómo llevar el mundo a cuestas? (Madrid: Museo Nacional Centro de Arte Reina Sofía, 2011), p. 112.

${ }^{62}$ Didi-Huberman, G. Atlas ¿ Cómo llevar el mundo a cuestas?... 112.

${ }^{63}$ Didi-Huberman, G. Atlas ¿Cómo llevar el mundo a cuestas?... 112. 
formalizada por normas de realización de un dibujo que identifica la imagen como un sustituto del original: "este es el objeto que he representado fruto de mi experiencia artística y estética”, podría afirmar el mismo Almendáriz. Dejando así, abiertas las posibilidades a cualquier observador de la época que nunca haya visto el objeto, con el que el dibujante compartiría su experiencia. Porque no podemos olvidar que los dibujos de Almendáriz se realizan para ser incorporados a un Informe, por lo que se les presume una condición como fuente documental. Aunque sobre esta condición, había que establecer que esta objetividad documental está prevista desde la idea que el observador con el que comparte su experiencia tenga muy presente que está viendo una imagen producto de procedimientos artísticos y estéticos que ambos comparten, y no frente a un calco, y mucho menos ante una fotografía del objeto. De manera, que el mismo Informe, en su conjunción como contenedor de palabras e imágenes, lo que pretende es dar cuenta de las experiencias sufridas ante los objetos, no presentar los objetos exentos de estas experiencias; lo que va también a matizar la idea inocente de la objetividad documental. Lo que convierte a las palabras (descripciones de Antonio del Río) y a las imágenes de Almendáriz, en los verdaderos objetos de estudio; ya que como prueba y testimonio, son trasmisores de los postulados y referentes occidentales que permiten la incorporación visual de un objeto no occidental, al universo visual de nuestra cultura. Además, y puesto que por los momentos no existía posibilidad de descifrar los contenidos lingüísticos de los glifos representados, no existía "piedra Roseta" que sirviese de intermediaria entre lo que se conocía y lo que se desconocía, la experiencia estética-artística adquirió, en la anticuaria ilustrada americana una valoración extraordinaria y trascendental.

En resumen. Estamos ante imágenes que son el resultado de la ampliación de las fronteras visuales, estéticas y artísticas, del proyecto de la modernidad ilustrada europea. Mundos incorporados al concepto occidental de lo exótico. Ampliación de los márgenes del clasicismo greco-latino. Objetos del otro, que a su vez sirven para definir lo que es nuestro. 


\section{Imágenes}

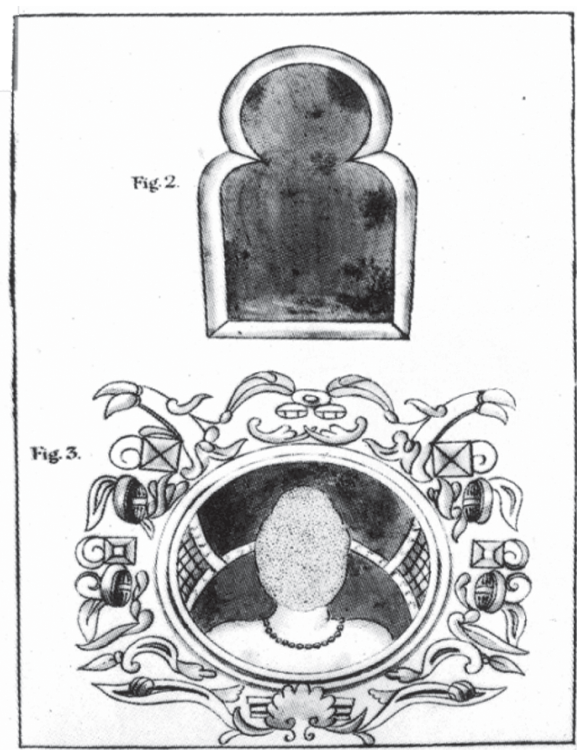

Imagen 1. Almendáriz. Decoración de la Gran Casa. Palenque.

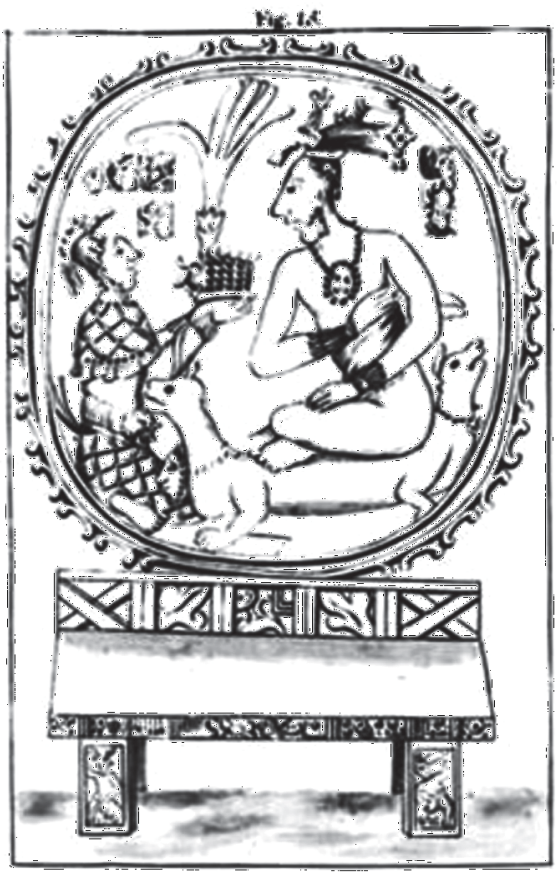

Imagen 2. Almendáriz. Trono del Palacio. Palenque. 
La antigua ciudad maya de Palenque en el debate ilustrado...

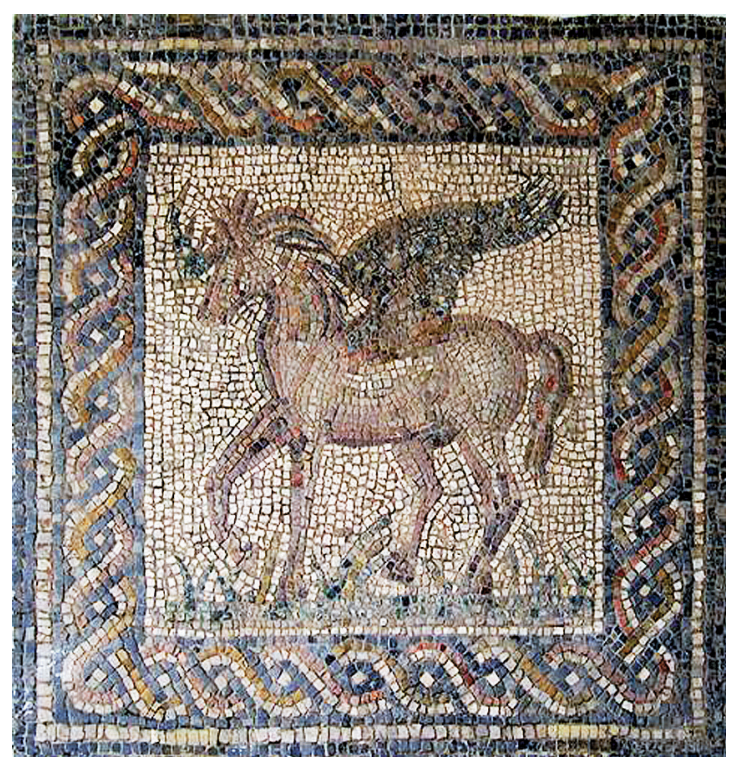

Imagen 3. Pegaso. Mosaico romano del siglo II d.C. Museo Arqueológico de Córdoba.

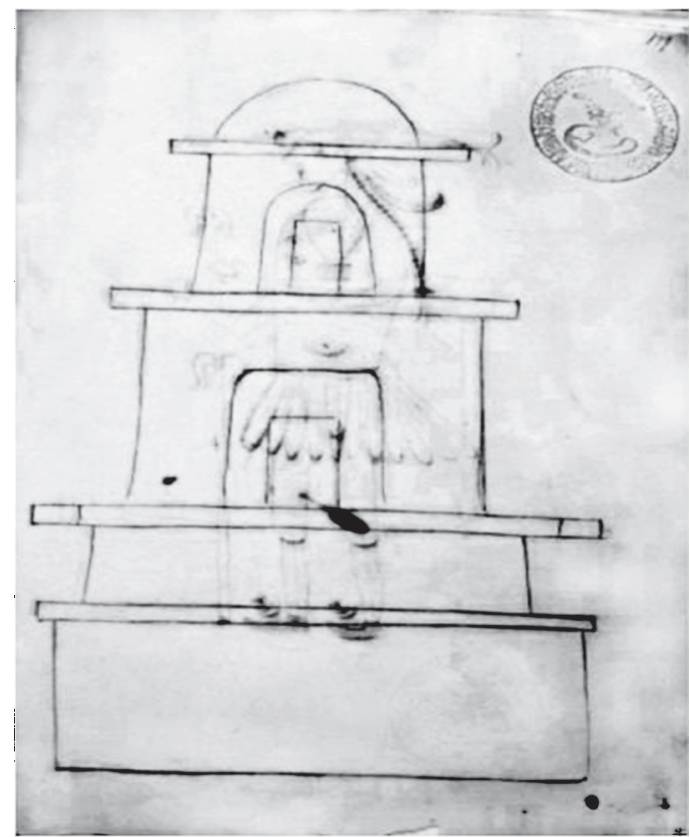

Imagen 4. Calderón. Dibujo de la Torreo de Palenque (A.G.I., M y P Guatemala, fol. 256 [2] bis). 


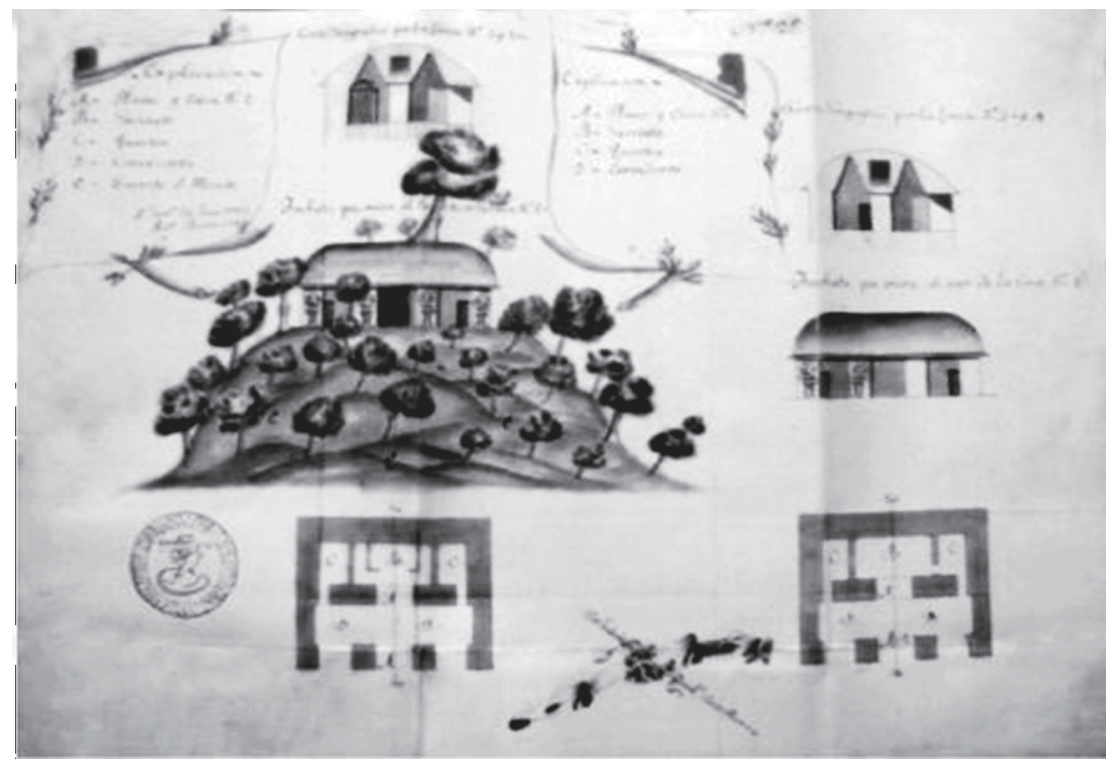

Imagen 5. Bernasconi. Plano de la ciudad de Palenque (A.G.I., M y P Guatemala, 258).

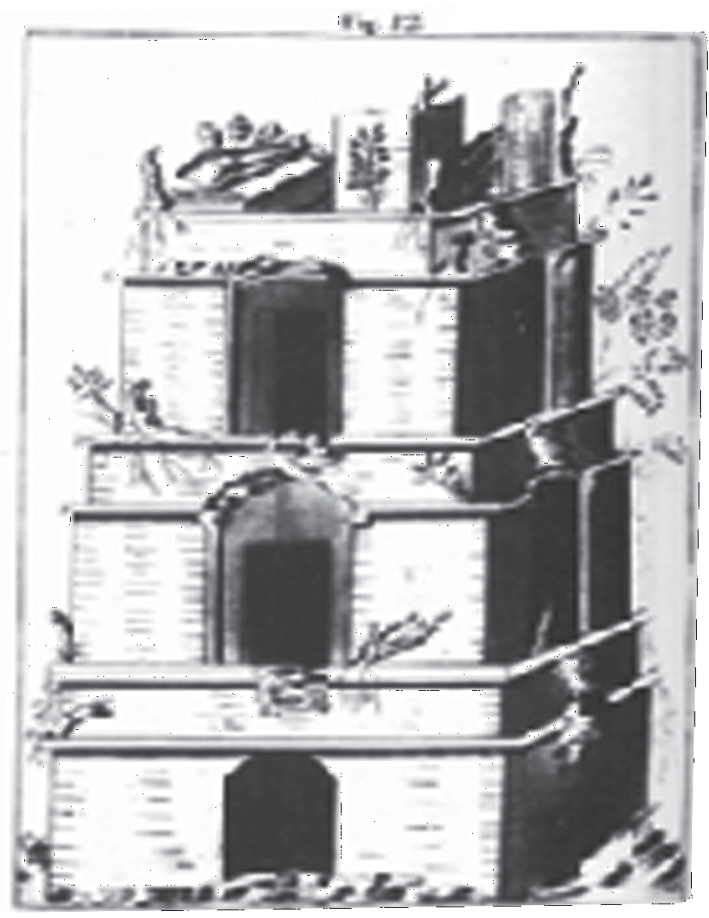

Imagen 6. Almendáriz. Torre de Palacio. Palenque. 1787. 
La antigua ciudad maya de Palenque en el debate ilustrado...

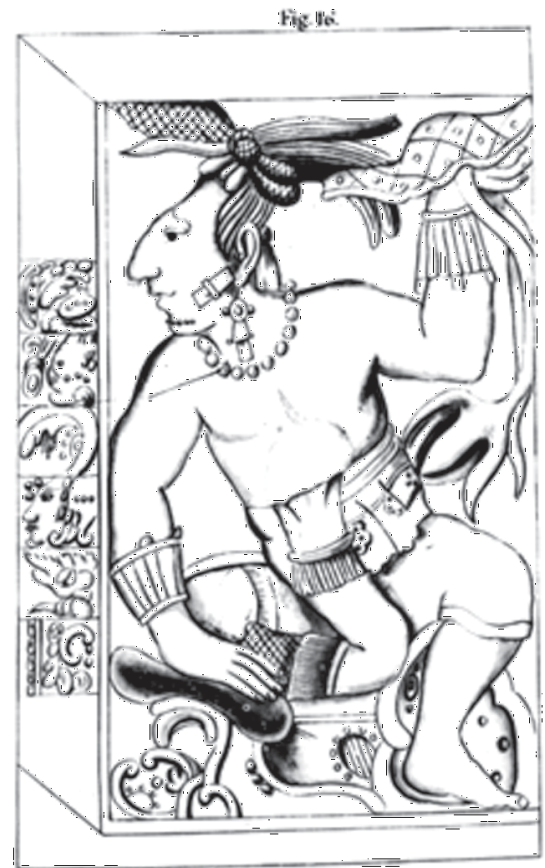

Imagen 7. Almendáriz. Pie derecho del Trono del Palacio. Palenque.

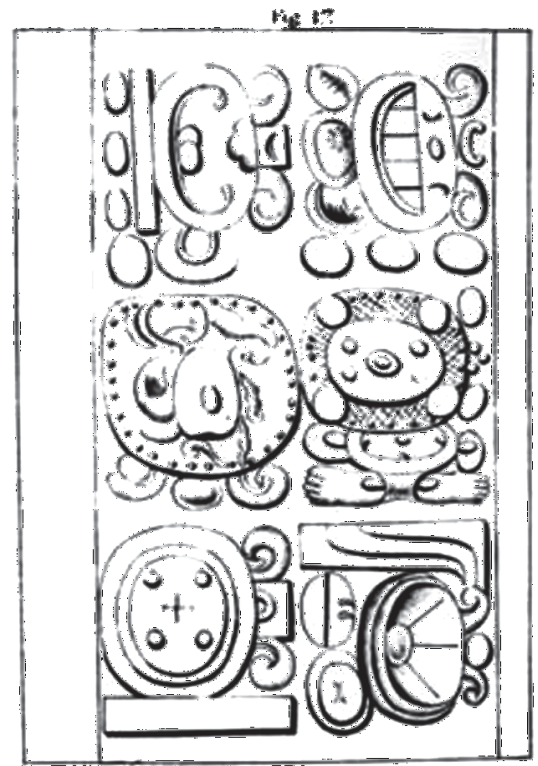

Imagen 8. Almendáriz. Dibujo de los grifos del pie derecho del trono. Palenque. 


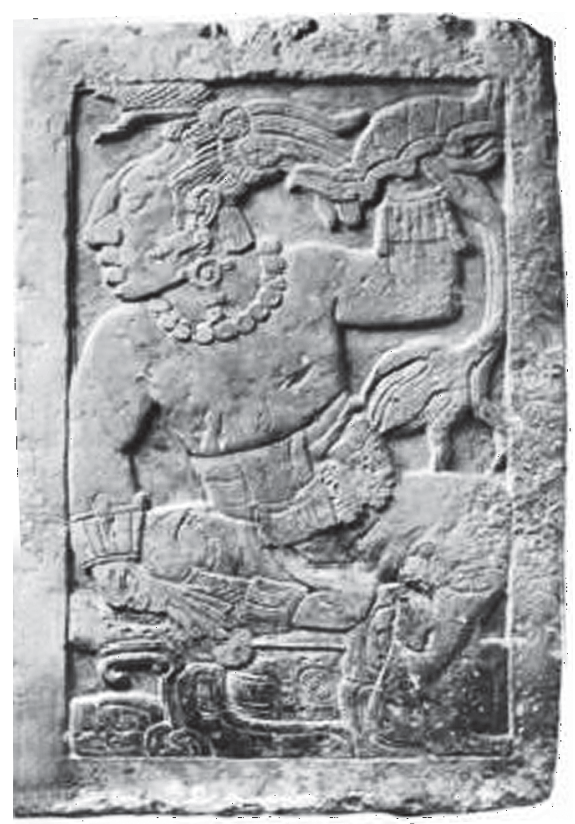

Imagen 9. Fotografía del pie derecho del trono. Palenque. Museo de América. Madrid.

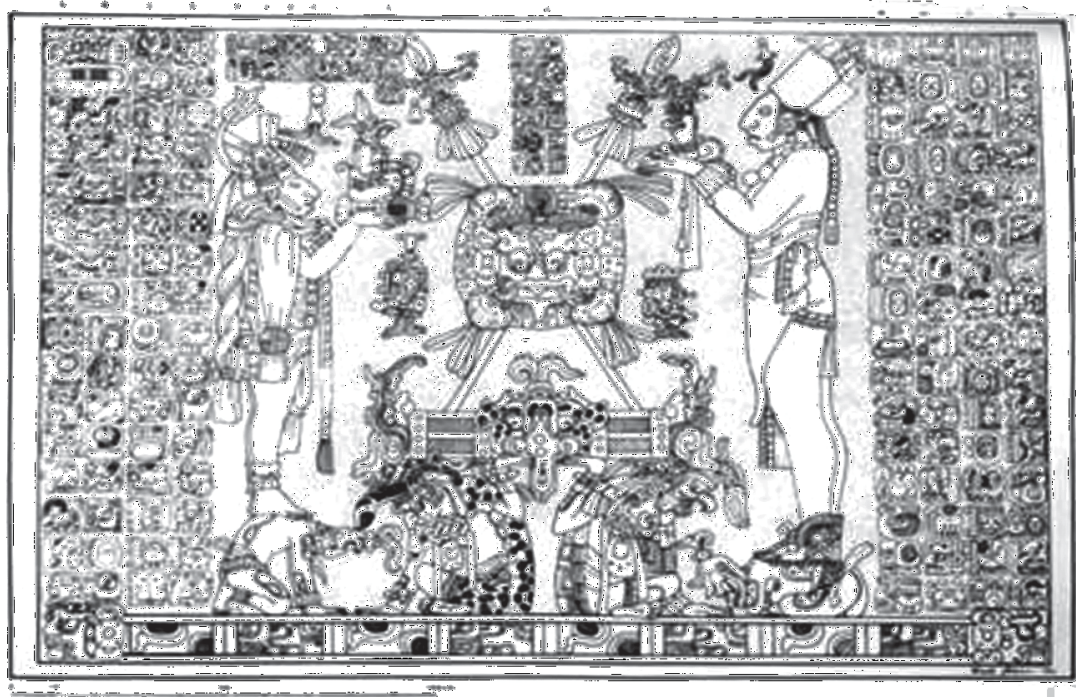

Imagen 10. Green. Calco del bajorrelieve central del Templo del Sol. Palenque, 1985. 


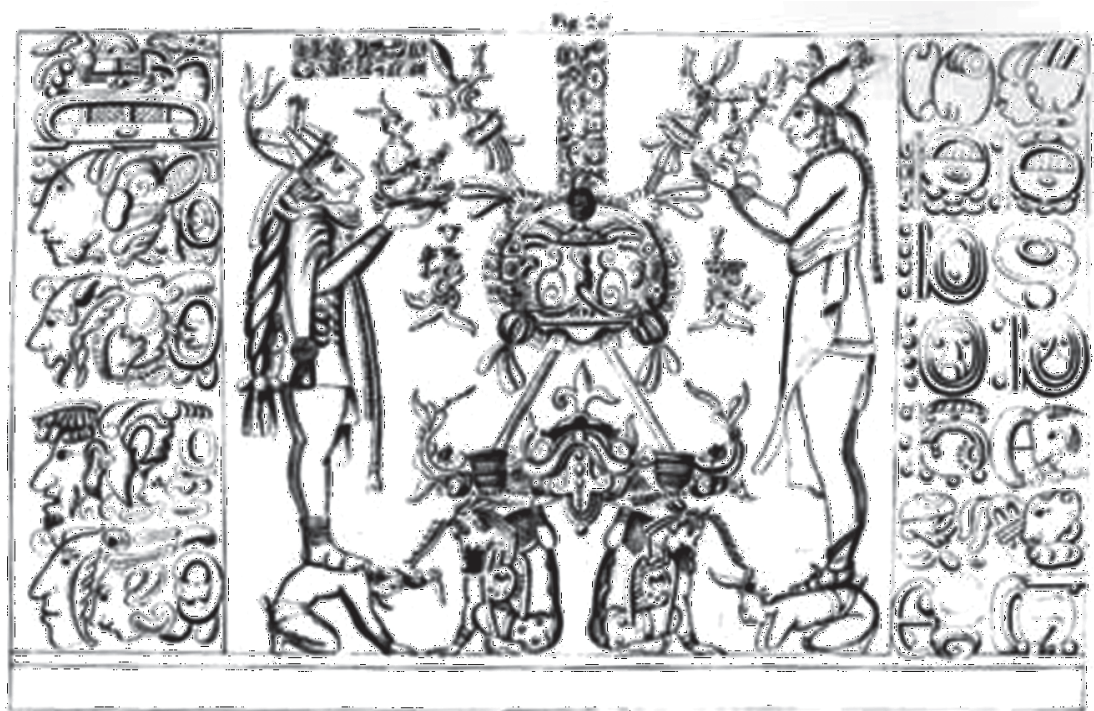

Imagen 11. Almendáriz. Bajorrelieve central del interior del Templo del Sol. Palenque.

\section{Fuentes documentales}

Del Río, Antonio. "Informe de Antonio del Río. Palenque, 24 de junio de 1787", en Cabello, Paz. Política investigadora de la época de Carlos III en el área maya. Descubrimiento de Palenque y Primeras excavaciones de Carácter Científico Madrid: Ediciones de la Torre, 1992, pp. 130-147.

Estachería, José. "Oficio de José Estachería a José Antonio Calderón. Guatemala, 28 de noviembre de 1784 (en copia del 29 de enero de 1985)". En Cabello, Paz. Política investigadora de la época de Carlos III en el área maya. Descubrimiento de Palenque y Primeras excavaciones de Carácter Científico. Madrid: Ediciones de la Torre, 1992. pp. 78-79.

Muñoz, Juan Bautista. "Oficio de Juan Bautista Muñoz al Marqués de Sonora (Gálvez), dictaminando sobre 
las ruinas de Palenque. Madrid, 7 de marzo de 1786", en Cabello, Paz, Política investigadora de la época de Carlos III en el área maya. Descubrimiento de Palenque y Primeras excavaciones de Carácter Científico. Madrid: Ediciones de la Torre, 1992, pp. 118-122.

"Oficio de José Estachería a José de Gálvez, Guatemala, 13 de febrero de 1785", En Cabello, Paz. Política investigadora de la época de Carlos III en el área maya. Descubrimiento de Palenque y Primeras excavaciones de Carácter Científico (Madrid: Ediciones de la Torre, 1992. pp. 103104.

"Oficio de José Estachería al Marqués de Sonora (Gálvez). Guatemala, 12 de agosto de 1786”. En Cabello, Paz. Política investigadora de la época de Carlos III en el área maya. Descubrimiento de Palenque y Primeras excavaciones de Carácter Científico (Madrid: Ediciones de la Torre, 1992. pp. 128-129.

"Real orden al Presidente de Guatemala (Estachería). El Pardo, 15 de marzo de 1786”. En Cabello, Paz. Política investigadora de la época de Carlos III en el área maya. Descubrimiento de Palenque y Primeras excavaciones de Carácter Científico (Madrid: Ediciones de la Torre, 1992. pp. 126-127.

\section{Bibliografía}

Ballesteros, Manuel. "Nuevas Noticias sobre Palenque en un manuscrito del siglo XVIII", Cuadernos del Instituto de Historia. Serie de Antropología, No. 11 (1960): 5-42.

Cabello, Paz. Política investigadora de la época de Carlos III en el área maya.

Descubrimiento de Palenque y Primeras excavaciones de Carácter Científico, Madrid: Ediciones de la Torre, 1992. 
La antigua ciudad maya de Palenque en el debate ilustrado...

Didi-Huberman, Georges. Atlas ¿Cómo llevar el mundo a cuestas? Madrid: Museo Nacional Centro de Arte Reina Sofía, 2011.

García Saíz, Concepción. "Antonio del Río y Guillermo Dupaix. El reconocimiento de una deuda histórica". En: Anales del Museo de América, No. 2 (1994).

Laporte, J. P; Escobedo, H; Villagran, S (edts). Memorias. VI Simposio de Investigaciones Arqueológicas en Guatemala. Guatemala: Museo Nacional de Arqueología y Etnología, 1992.

Paillés, María de la Cruz y Nieto, Rosalía. "Palenque en el siglo XVIII, primeras expediciones de la Corona Española: Joseph Antonio Calderón y Antonio Bernasconi”, en Laporte, J. P; Escobedo, H; Villagran, S (edts). Memorias. VI Simposio de Investigaciones Arqueológicas en Guatemala, (Guatemala: Museo Nacional de Arqueología y Etnología, 1992. pp. 474-504.

\section{Citar este artículo:}

Antonio E. de Pedro Robles, "La antigua ciudad maya de Palenque en el debate ilustrado sobre la anticuaria indígena americana", Revista Historia y Memoria, No. 08 (enero-junio, 2014), pp. 59-101 